\begin{tabular}{|c|c|}
\hline \multirow{3}{*}{ 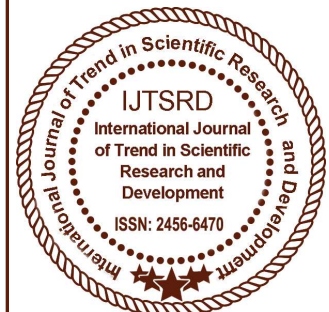 } & $\begin{array}{l}\text { International Journal of Trend in Scientific } \\
\text { Research and Development (IJTSRD) }\end{array}$ \\
\hline & International Open Access Journal \\
\hline & ISSN No: 2456 - 6470 | www.ijtsrd.com | Volume - 1 | Issue - 6 \\
\hline
\end{tabular}

\title{
A Critical Study on the Relationship Between E-Learning \& its Proper Subset Blended Learning in Higher Education
}

\author{
Shyamal Kumar Das \\ Vice Principal of HS School, Mathematics Teacher \& \\ Master Resource Person in Mathematics, Trained \\ under NERIE, M.Sc. (Math), MA (Edn), B.Ed.(Ph.D. \\ scholar, Jharkhand Rai University, India
}

\section{ABSTRACT}

In today's age of virtually instantaneous access to a vast repository of knowledge and information, learning resources are often considered as key intellectual property in a competitive world, more and more institutions and individuals are sharing elearning resources over the Internet openly and without cost, as open educational resources (OER). But in student's learning domain it got reverse impact even in spite of several favourable impact, depending on how prudently is used, as it leads to unsupervised education system and that may prone to develop misconception. This study is fashioned to create a scalable intervention to measure the relationship between the e-learning and its proper subset blended learning of the students of higher education, perceived by their teachers. To address this issue college teachers of Kolkata (WB) constitute the population. A sample of 200 teachers was selected. A16-items selfdeveloped questionnaire $(r=0.87362)$ was used to measure the teachers' perception about e-learning and blended learning of their students. The obtained data were analysed and interpreted by using descriptive statistics, t-test, and one way ANOVA. The result reveals blended learning encourages healthy learning to the students.

Keywords: Intellectual property, e-learning, Blended learning

\author{
Radheswar Roy \\ English Teacher, MA (Eng), MA (EVS), B.Ed., \\ M.Phil (Eng), Ph.D. scholar, Jharkhand Rai \\ University, India
}

\section{INTRODUCTION}

Our future education tremendously converging towards digitised, personalised, and blended learning (where blended learning is a proper subset of elearning) with the inclusion of ICT tools in education, which got tremendous impetus in teaching and learning process without denying the value of printed version. In this digitised world ILT (Information and Learning Technologies) is the use of ICT to delivery, support-management, and enhance teaching and learning, has become more challenging compared to their traditional counter parts. e-learning is no longer a trend but a fact become easier due to access of OER through internet, knowledge is abundantly available, numerous attempts for mock tests, self-evaluation system and self-pacing and autonomous study, developing competences and career through internet in the click of a figure that made learners more tech savvy than receiving instructional guidance and updates only from classroom face-to-face learning.

Internet is the storehouse of information but all the information are not valid and reliable. Matured students can judiciously access into Internet through discerning and discriminating credible resources from the not-so-credible one, but young students solely belief the answers by goggling it. It demands for careful guidance and mentoring of teachers. Due to maximum dependency on e-learning, students always try to learn easy and fast hinderelaborate study to acquire the overall knowledge and facts that reduce their span of attention, retention, and recollection 
capabilities. And I doubt about their creative construct may be threatened. Unless e-learning is made formally structured and brought under super vision that may prone to misconception, erroneous learning of important concepts and ideas and its effect could be irreparable. Blended learning is a pedagogical approach comes in many guises and is not a "onesize-fits-all" educational solution. It is a thoughtful integration of individualised student-centred traditional face-to-face in class learning supplemented by online activities and resources. This concept may be represented by,

Blended learning model $=$ Essential traditional in class learning +Unparalleled access to internet with rich resources of information and services in learning (e-learning) + [Creation of online communities and support networks + Growing use of mobile technologies].

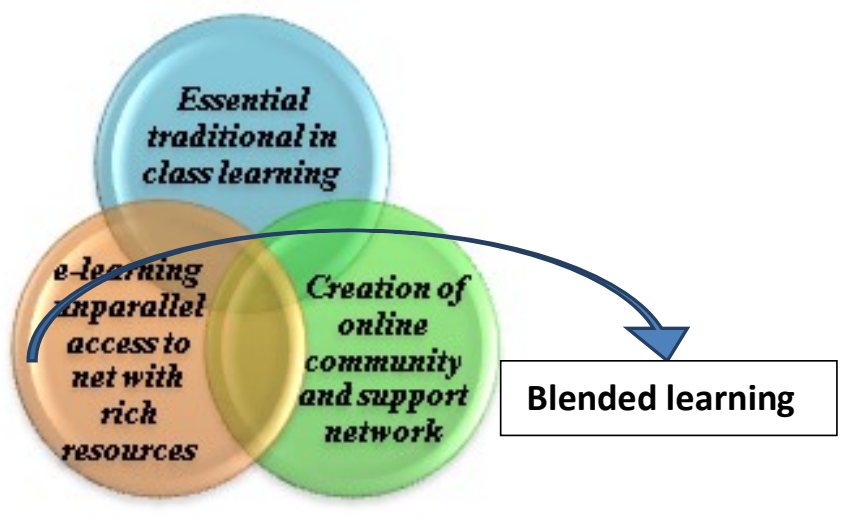

Table No. 1.0: Represents the Venn-diagram of Essential traditional in class learning, e-learning unparallel access to net with rich resources, and Creation of online community and support network and their intersection the Blended learning.Table No. 1.0: Represents the Venn-diagram of Essential traditional in class learning, elearning unparallel access to net with rich resources, and Creation of online community and support network and their intersection the Blended learning.

\section{MATERIAL AND METHODOLOGY}

\subsection{Population and Sample}

In the present investigation all the college teachers of Kolkata were the population of this study. Based on random sampling technique the researcher selected 200 college teachers from six colleges (100 teachers from traditional colleges and 100 teachers from technical colleges) of Kolkata.

\subsection{Objectives of the study}

To determine whether or not there is presence in performance under and between the E-learning and blended learning among and between the college students of Kolkata (West Bengal), perceived by their teachers.

To determine whether or not there is presence of correlation among and between all the independent variables(Essential traditional in class learning, Unparalleled access to internet with rich resources of information and services in learning (e-learning), Creation of online communities and support networks, Growing use of mobile technologies) of blended learning perceived by the college teachers of Kolkata (West Bengal).

\subsection{Tools used in the study}

To collect data from sample groups the researcher used self-developed 24-items questionnaire with all positive statement. Assessment is made under five points Likert's-format scale.

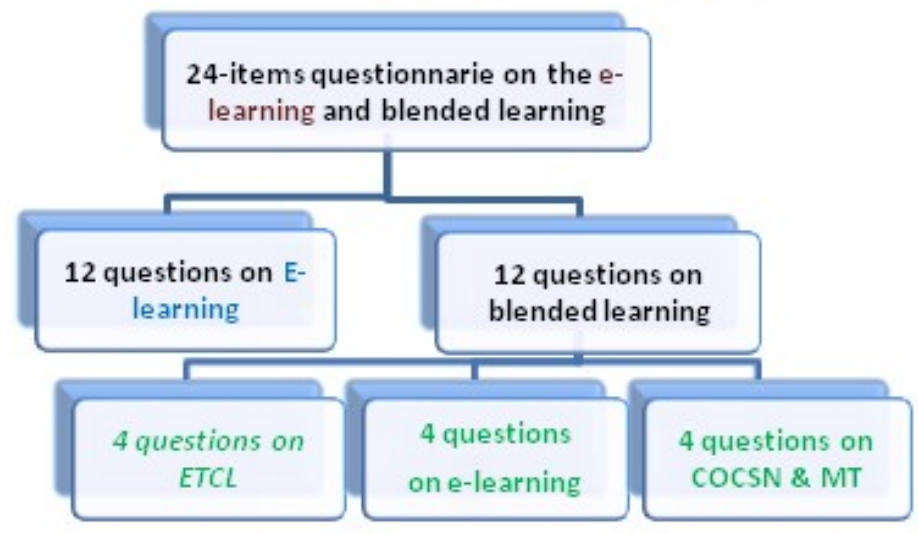


[Questions on E-learning are based on the students' performance in English, but the questions on elearning based on general access to internet with rich resources of information and services]

\subsection{Scope and Delimitation}

$>$ The study was conducted only for the year June and July 2017.

$>$ The study was conducted only for $1^{\text {st }}$ and $2^{\text {nd }}$ semester college students.

$>$ The study was conducted only for the subject English, not for other subjects.

$>$ Only selected personal and institutional variable has been taken into consideration for the present study.

$>$ The study has been delimited to their i.e., teachers' perception about e-learning and blended learning of their students.

$>$ Further the findings have been subjected to the limitations of tools used and statistical treatment used.

\subsection{Hypothesis of the Study}

$\mathrm{H}_{01}$ : There is no significant difference in performance under and between the E-learning and blended learning among and between the college students of Kolkata (West Bengal), perceived by their teachers.

$\mathbf{H}_{02}$ : There is no significant difference among and between all the independent variables(Essential traditional in class learning, Unparalleled access to internet with rich resources of information and services in learning (e-learning), Creation of online communities and support networks, Growing use of mobile technologies) of blended learning perceived by the college teachers of Kolkata (West Bengal).

\section{STATISTICAL ANALYSIS GRAPHICAL REPRESENTATION}

AND

Under descriptive statics mean, and slandered deviation against the score of Essential traditional in class learning (ETCL), Unparalleled access to internet with rich resources of information and services in learning (e-learning), Creation of online communities and support networks, Growing use of mobile technologies (COCSN \& MT), Blended learning and E-learning are presented in the below mentioned table.

\begin{tabular}{|l|l|l|l|l|l|}
\hline & ETCL & $\begin{array}{l}\text { e- } \\
\text { learning }\end{array}$ & $\begin{array}{l}\text { COCSN } \\
\text { \& MT }\end{array}$ & $\begin{array}{l}\text { Blended } \\
\text { learning }\end{array}$ & $\begin{array}{l}\text { E- } \\
\text { learning }\end{array}$ \\
\hline N & 200 & 200 & 200 & 200 & 200 \\
\hline Mean & 16.395 & 14.035 & 13.555 & 43.985 & 39.245 \\
\hline SD & 1.999 & 1.978 & 2.229 & 3.8167 & 1.6285 \\
\hline
\end{tabular}

Table no. 3.0: Represents size of the sample, mean and $S D$ of different variables.

$\mathbf{H}_{01}$ : There is no significant difference in performance under and between E-learning and blended learning among and between the college students of Kolkata (West Bengal), perceived by the teachers.

\begin{tabular}{|c|c|c|c|c|c|}
\hline Teachers' Perception in & MD & SED & $\mathbf{t}$ & Sig. & $95 \%$ CI of Difference \\
\hline $\begin{array}{c}\text { Blended learning of } \\
\text { students }\end{array}$ & \multirow{2}{*}{$\stackrel{+}{\frac{1}{2}}$} & \multirow{2}{*}{$\begin{array}{l}\text { స̆ } \\
\text { ஸे }\end{array}$} & \multirow{2}{*}{$\frac{\overrightarrow{0}}{6}$} & \multirow{2}{*}{$\overline{\bar{\theta}}$} & \multirow{2}{*}{$\begin{array}{c}4.1649<4.74<5.3151 \\
\text { (Not containing "0" } \\
\text { hence significant) }\end{array}$} \\
\hline E-learning of students & & & & & \\
\hline
\end{tabular}

Table 3.1: Represents the significance difference in performance under and between E-learning and blended learning among and between the college students of Kolkata (West Bengal), perceived by the teachers.

From the table-3.1, the " $\mathrm{t}$ " difference between theperceived performance of the students by theirteachers under only e-learning and blended learning is 16.154 . Which is statistically significant as the $\mathrm{P}$-value is less than $0.05(\mathrm{P}=0.00001<0.05$, for 2 tailed) \& as the confidence interval of different parameters not containing Zero, there is statistical significance difference between means of two variables, at $95 \% \mathrm{CI}$ of difference. Hence the formulated null-hypothesis $\left(\mathbf{H}_{\mathbf{0 1}}\right)$ is rejected means; there is significant difference in performance under and between the e-learning and blended learning 
among and between the college students of Kolkata(West Bengal), perceived by the teachers.

The difference between means in the variables likely to be between 4.1649 and 5.3151

Reason: Teachers perceived a section of students judiciously can't access into Internet through discerning and discriminating credible resources from the not-so-credible one, some of those are not even authenticated. In addition learning through e-material and media is unsupervised, not used prudently and becomes prone to develop misconceptions and is irreparable. But under teachers' traditional in-class supervision the blended learning, impetus the credibility and potentiality of the students in learning and their performance become satisfactory.

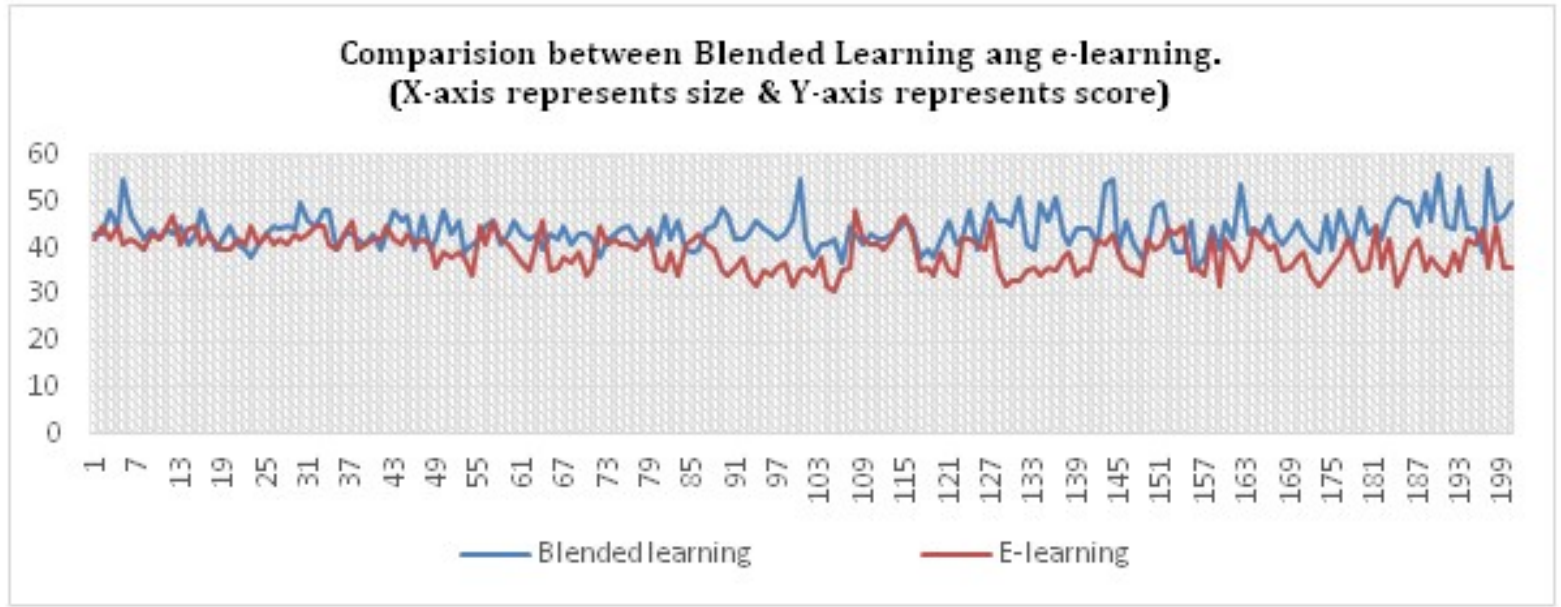

Fig. No. 3.1: Represents the correlation between blended learning and e-learning of the students' of Kolkata $(W B)$, perceived by their teachers.

$\boldsymbol{H}_{02}$ : There is no significant difference among and between all the independent variables (Essential traditional in class learning, Unparalleled access to internet with rich resources of information and services in learning (e-learning), Creation of online communities and support networks, Growing use of mobile technologies) of blended learning perceived by the college teachers of Kolkata (West Bengal).

\begin{tabular}{|c|c|c|c|c|c|c|}
\hline $\begin{array}{l}\text { Ind. } \\
\text { Variab } \\
\text { le }\end{array}$ & $\begin{array}{l}\text { Variati } \\
\text { on }\end{array}$ & $\begin{array}{l}\text { Eof } \\
\text { Square }\end{array}$ & df & $\begin{array}{l}\text { Mean } \\
\text { Squar } \\
\text { e }\end{array}$ & F & Sig \\
\hline ETCL & $\begin{array}{l}\text { Between } \\
\text { groups }\end{array}$ & $\begin{array}{l}924.37 \\
3\end{array}$ & 2 & $\begin{array}{l}462.18 \\
7\end{array}$ & \multirow[b]{3}{*}{$\begin{array}{l}* \\
\infty \\
\infty \\
\sigma \\
\vdots \\
0\end{array}$} & \multirow{3}{*}{$\begin{array}{l} \\
8 \\
8 \\
0\end{array}$} \\
\hline $\begin{array}{l}\text { e- } \\
\text { learnin } \\
\mathrm{g}\end{array}$ & $\begin{array}{l}\text { Within } \\
\text { groups }\end{array}$ & $\begin{array}{l}2562.5 \\
08\end{array}$ & $\begin{array}{l}59 \\
7\end{array}$ & 4.292 & & \\
\hline \begin{tabular}{ll}
\multicolumn{2}{l}{ COCS } \\
$\mathbf{N} \&$ \\
$\mathbf{M T}$
\end{tabular} & Total & $\begin{array}{l}3486.8 \\
82\end{array}$ & $\begin{array}{l}59 \\
9\end{array}$ & & & \\
\hline
\end{tabular}

** $\mathrm{P}<0.05$ Table $\mathrm{F}$, df $(2,597)=3.01 \& \mathrm{P}<0.01$ Table $\mathrm{F}, \mathrm{df}(2,597)=4.62$

Table-3.2: Represents the ANOVA of independent variables under Blended Learning.
The computed value of $\mathrm{F}$, i.e. 107.678 is much higher than both the critical value of $F$ at 0.05 and 0.01 levels of significance. Hence it should be taken as quite significant. Consequently the null-hypothesis $\boldsymbol{H}_{\boldsymbol{0} 2}$ is rejected means, There is significant difference among and between all the independent variables [Essential traditional in class learning (ETCL), Unparalleled access to internet with rich resources of information and services in learning (e-learning), \{Creation of online communities and support networks, Growing use of mobile technologies; (COCSN \& MT)] of blended learning (B.L) perceived by the college teachers of Kolkata (West Bengal). Hence at least one significant difference definitely exists between the group means.

The blended learning mean score for ETCL, elearning, and COCSN \& MT were 16.395, 14.035, and 13.555 respectively. To find out which of these paired mean had a significant difference, the Scheffe's post-hoc test was applied. 


\begin{tabular}{|l|l|l|l|l|}
\hline \multicolumn{3}{|c|}{ BLENDED LEARNING } & $\begin{array}{l}\text { Mean difference } \\
\text { \& sig. difference }\end{array}$ & $\begin{array}{l}\text { Comparison } \\
\text { Value }\end{array}$ \\
\hline $\mathbf{1 6 . 3 9 5}$ & 14.035 & & $2.360 * *$ & $\begin{array}{l}0.5083 \\
\text { As sample sizes } \\
\text { are same }\end{array}$ \\
\hline & 14.035 & 13.555 & 0.480 & $2.840 * *$ \\
\hline
\end{tabular}

Table-3.3: Represents Scheffe's Post-hoc test for significance difference in Blended learning of different variables.

The table-3.3 shows that the significant paired means difference in the ETCL \& e-learning and ETCL \& (COCSN \& MT) levels of blended learning are 2.360 and 2.840 , those are greater than the comparison value 0.5083 and no significant paired mean difference in blended learning between e-learning \& (COCSN \& MT) is 0.480 , that is less than the comparison value 0.5083. It is concluded that the effectiveness and potentiality of the variable Essential traditional in class learning (ETCL) is better than that of e-learning and Creation of online communities and support networks, Growing use of mobile technologies (COCSN \& MT).

\section{DISCUSSION AND SUGGESTION}

E-learning is any type of learning that is facilitated by technology or by instructional practices that makes effective use of ICT tools/technology, it occurs in all learning areas and domain. It provides 24X7 accessibility to course materials and just-in-time methods to access and evaluate learners progress. At present there is the existence of multiple channels of knowledge discovery and available Open Educational Resources (OER) over Internet without cost, facilitating the most challenging teaching and learning design that proliferate and leverage learning how to reason logically, interpret rationally, and think critically \&creatively. It is beyond doubt that this has made learning more interesting and entertaining when our institutions are less concerned about the dissemination of knowledge and information in industrialised mode to students without considering the individuality. Using technology no doubt learning become ubiquitous through online but unfortunately it leads to unsupervised system of learning, that reduced retention and attention span of the students, immediate feedback mechanism may available through the same media but no scope for AFL (Assessment for learning) that creates feedback used to improve student's performance with the diagnostic and remedial teaching.
As opposed to a purely online e-learning experiences, its subset, blended learning provide immense potential benefit of students either from peer or social interactions where access and create knowledge by means of power points, video presentation in classroom discussions that add interactivity and personalization over planned presentation of learning materials and receive feedback tutorials from a live lecture.

To facilitate both teachers and students, four blended learning model could be undertaken:

> Traditional face-to-face teaching part, where students are free to access their teachers, for gain and clarification of doubts are to be enhanced by sagacious designing.

$>$ Direct acceptance of critical and complicated information through e-learning may be a erroneous learning. Hence that should be consulted or discussed with teachers, experts, or other different e-sources.

$>$ For e-learning update rich informatics, designed and developed material are to be arrange logically for dissemination under professional course developers.

$>$ There must be high powered e-censure board to control and maintain the slandered of e-learning materials

\section{REFERENCE}

1) Al-Jarf, R.S.(2004). The effect of web-based learning on struggling EFL college writers. Foreign Language Annals, 37(1), 49-57.

2) Barab, S.A., Squire, K., \&Duebar, B. (2000). Supporting authenticity through participatory learning. Educational Technology Research and Development, 48(2), 37-62.

3) Book Digitisation Project Gathers Pace. (2007, December/January) Research information, 27, and 10. 
4) Caldwell, E.R. (2006). A comparative study of three instructional modalities in a computer programmingcourse : Traditional instruction, web-based instruction, and online instruction, (Doctoral dissertation).Retrieved fromProQuestDissertation and Theses database(UMI No.AAT3227694).

5) Cox,J.(2004), E-Books: Challenges and opportunities. D-Lib Magazine, 10(10). Retrieved $30^{\text {th }} \quad$ Aug, 2017, from http://dlib.org/dlib/oct.04/cox/10cox.htlm.

6) Deshmukh, S.G.,IITDelhi,(May 31 ${ }^{\text {st }}$ 2014), Bhattcherjee, Simon Fraser University,(June $\left.4^{\text {th }}, 2014\right)$, E-learning : Pedagogy and Education, Retrieved $30^{\text {th }} \mathrm{Aug}, \quad 2017$, from http://www.researchgate.net.

7) Gilliver, R.S., Randall, B., \&Pok, Y.M.,(1998). Learning in cyberspace : Shaping the future.Journal of Computer Assisted Learning, 14(3), 212-222.
8) Mentzer, G.A., Cryan, J., \&Teclehaimanot, B.(2007). A comparison of face-to-face and webbased classroom.Journal of Technology and Teacher Education, 15(2), 233-246.

9) Schreiber,E.,Fukuta, J., and Gordon, F., "Live lecture versus video podcast in undergraduate medical education : A randomizer controlled trial," BMC Medical Education,2010.

10) Watson, J.F.(2008). Blended learning: The convergence of online learning and face-to-face education. Retrieved from http://www.inacol.org/resources/promisingpractic es/NACOL_PP-Blended Learning-lr.pdf 